\title{
Preparation of Oil-in-Water Emulsion with a Good Texture of Use and Waterproofness Using the Gemini Surfactant*
}

\author{
Norio Sekiguchi, Katsuya Shimizu \\ Functional Surfactant Research \& Development Department, Asahikasei Chemicals Co. **
}

\begin{abstract}
We investigated the development of an $\mathrm{o} / \mathrm{w}$ emulsion with a good texture of use and waterproofness. We considered the Gemini-type surfactant, which can disperse oil using a small amount of emulsifier, to be suitable to achieve the objectives, and investigated using sodium dilauramidoglutamide lysine (International Nomenclature of Cosmetic Ingredients (INCI) name; a Geminitype compound obtained by treating sodium lauroyl glutamate with lysine). We report that the expected good results were obtained. The critical micelle concentration of sodium dilauramidoglutamide lysine was found to significantly decrease compared with a monomer (sodium lauroyl glutamate), and we evaluated the emulsifying capacity. As a result, sodium dilauramidoglutamide lysine, can emulsify various types of oil with a small amount $(0.03$ to $0.1 \%)$ regardless of the blended amount (10 to 50\%), and the emulsion showed good stability (almost no change in the particle size between the baseline and after 1 month at $50^{\circ} \mathrm{C}$ ). In a comparison of the waterproofness between the emulsion prepared with sodium dilauramidoglutamide lysine and that emulsified by a non-ionic surfactant using the cup-shaking method, the former contained more components in the oil phase in the skin or hair. In addition, it was less oily, could be spread more smoothly, and provided a fresh texture of use after application compared with a non-ionic surfactant since it was emulsified in a small amount.
\end{abstract}

Key words : a good texture of use, waterproofness, o/w emulsion, Gemini-type surfactant, sodium dilauramidoglutamide lysine, good stability, sodium lauroyl glutamate, small amount of emulsifier, particle size, almost no change

* Received, August 17, 2015; Accepted, July 7, 2016

** 1-3-1, Yakoh Kawasaki-ku, Kawasaki 210-0863, Japan

doi.org/10.5107/sccj.51.18

(C) 2017 The Society of Cosmetic Chemists of Japan 


\title{
ジェミニ型界面活性剤を用いた使用感に優れた 耐水性 O $/ \mathrm{W}$ エマルジョンの調製*
}

\author{
関口範 夫, 清 水克也
}

旭化成ケミカルズ株式会社 機能活性剂技術開発部**

\begin{abstract}
使用感が良好で耐水性に優れた O / W エマルジョン製剤の検討を行った。油と水の界面張力を下 げるノニオン系界面活性剂を用いた乳化物は, 使用感や再乳化され耐水性が悪いことから, 物理的な 力で（機械的に）乳化させ，乳化剂は少量で行うことができれば使用感も良好であると予測した。こ の機能を達成するにはジェミ二型の界面活性剤が適していると考え, ラウロイルグルタミン酸 Na を リジンで連結させたジラウロイルグルタミン酸リシン Na を合成し, 表面張力測定や乳化力, カップ シェイク法による耐水性などの検討を行った。その結果, ジラウロイルグルタミン酸リシン Na はモ ノマーに比べ臨界三セル濃度が低く, 少量 $(0.03 \sim 0.1 \%)$ で油の種類や量に関係なく乳化が可能であ り, 経時による粒径変化が少なかった。また, 少量の界面活性剤で乳化された乳化物は, ノ二オン系 界面活性剂による悪い使用感（べたつき感など）が少なく，再乳化されにくいので耐水性に優れ，皮 膚や毛髪に油分を多く残存する結果でもあった。以上の結果から, ジラウロイルグルタミン酸リシン Na を乳化剂として使用すると, 使用感が良く耐水性にも優れた乳化物が得られることがわかった。
\end{abstract}

\section{1. 緒言}

クリームや乳液などの乳化製品は大きく分けて油相成 分，水相成分，乳化剤から構成されて㧍り，配合する成分 によって使用感も大きく異なる。乳化剂の配合比は油相成 分や水相成分と比較すると少ないが，使用感に大きな影響 を及ぼすことが一般的に知られている。そのため多くの処 方担当者は乳化剂の配合量を少なくする工夫（D 相乳化や 転相乳化など）や使用感の良い乳化剂を選択したりしてい るが, 乳化剤の選択を誤ると分離などの化粧品本体の品質 に影響を与える可能性が大きい。そこで処方担当者は実績 のある乳化剂や配合比での検討を優先的に行うことが多 く, 新規の乳化剂を検討する場合は, 慎重な作業と大変な 労力が必要とされている。一般的には乳化力が強く実績も ある EO 付加の乳化剂が汎用されているが，石油系の界面 活性剂として消費者から嫌われる傾向にあり, 近年は植物 系のイメージをもつポリグリセリン脂肪酸エステルやショ 糖脂肪酸エステル系のノニオン系界面活性剂を配合する傾 向にある。しかし，乳化ができる油種が限定されたり，乳 化力が弱く分離しやすいため乳化剂の使用量を多くする必 要が発生したりするので, 乳化が難しくコストなどの問題

\footnotetext{
*2015.8.17 受付, 2016.7.7 採用

** $\overline{2} 210-0863$ 川崎市川崎区夜光 1-3-1
}

に直面するといわ机ている。

また，サンスクリーン製剂は日焼けを防ぐ目的で開発さ れているために紫外線吸収剤や散乱剂を長時間にわたって 肌に留めておくよう，W／OOのように連続相を油相とする 剂型が一般的である。そのため使用感が「油っぽい」感触 になり消費者に嫌われやすい。一方，連続相を水相にした $\mathrm{O} / \mathrm{W}$ にすれば「みずみずしく，しっとり」とした使用感 になるが, 水と油の界面張力を下げて乳化しているので, 水や汗によって再乳化され，紫外線吸収剤や散乱剤は流れ やすく，日焼けを防ぐ性能が低下しやすいという問題があ る。これを解決する目的で $\mathrm{O} / \mathrm{W}$ 製剤に耐水性が高い皮 膜形成剂を配合する処方が提案されているが，「塗布時の 伸びが悪く, 塗布後の閉塞感がある」など使用感が劣るこ とが多い。

そこで使用感が良好で耐水性に優れた $\mathrm{O} / \mathrm{W} エ マ ル$ ジョンの開発を目的に検討を行った。この目的を達成する には，使用感は界面活性剂量が少ないほうが，耐水性は乳 化粒子に吸着する界面活性剂の分子数が少ないほうが良い （乳化粒子が壊れやすく油を放出しやすい）と思われる。 吸着する分子数を少なくするには，単純に界面活性剤の分 子量を大きくすれば良いと考えられるが，単純に親水基を 大きくすると, 最少ミセル濃度が高くなり配合量を多くす る必要性が生じたり，逆に親油基を大きくすると $\mathrm{W} / \mathrm{O}$ エマルジョンになりやすい。親水基と親油基の両方を大き 
くすると, HLB が変化したり融点が高くなり扱いにくく なることが予想された。そこで, 従来の一鎖一親水基など の界面活性剤を用いると分子設計が難しいと推定されたの で，分子量を上げられ親油基と親水基性の両方をバランス 良く高められる構造をもつ, ジェミニ型（多鎖多親水基） の構造式が適していると考えた。そこで，2つのラウロイ ルグルタミン酸 $\mathrm{Na}$ (一鎖一親水基)をリジンで連結させ てジェミニ化（多鎖多親水基）した化合物を合成し，ジラ ウロイルグルタミン酸リシン Naを用いて検討を行った (Fig. - 1)。ジラウロイルグルタミン酸リシン Naは植物由 来のペプチド骨格を有するジェミニ型のアニオン系界面活 性剤であり, ラウロイルグルタミン酸 $\mathrm{Na}$ と比較して $\mathrm{cmc}$ が低く, 乳化剂として用いると上記の課題が解決できるこ とがわかった。すなわち, ジラウロイルグルタミン酸リシ ン $\mathrm{Na}$ は低濃度（0.03〜0.1\%；濃度はすべて固形分で表示）
で油種や配合量に関係なく乳化が可能であることに加え， アニオン系であるために，O/Wエマルジョンにした場合 の油滴の周りはアニオン性を帯びているので，合一が起き にくい乳化物であることがわかった。また，少量（0.1\% 以下）の乳化剂で乳化しているので，使用感が良好で従来 の HLB 方式に代表されるような油と水の界面張力を下げ て乳化するのでなく，機械的に分散するため，皮膚に塗布 した乳化物の皮膜は, 汗や水分が付着しても再乳化されに くいために耐水性も優れた乳化物であることもわかった。

\section{2. 実 験 方 法}

\section{1. 表面張力の測定}

Wilhelmy 法 $\left(25^{\circ} \mathrm{C}\right)$ で行った。

\section{2. 乳化物の調製}

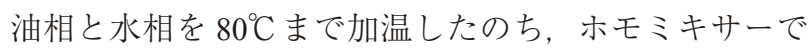

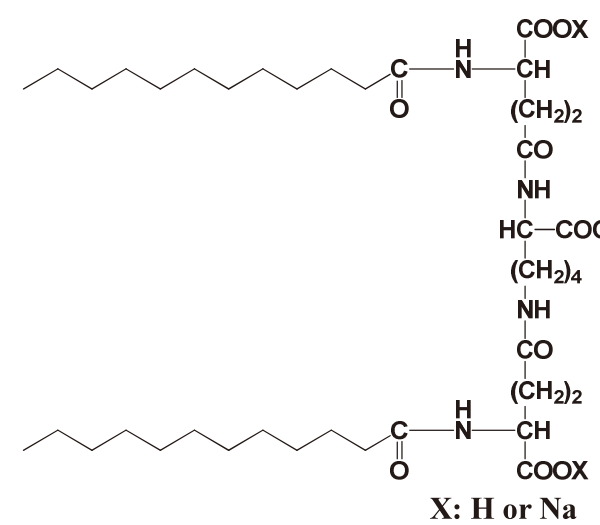

coox

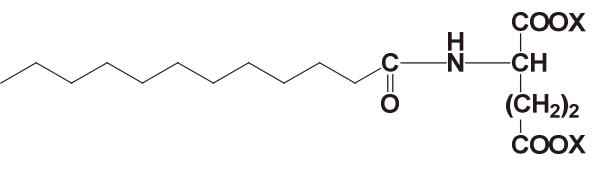

Sodium lauroyl glutamate

(Monomer)

Sodium dilauramidoglutamide lysine (Gemini compound)

Fig. -1 Structural formula of Sodium dilauramidoglutamide lysine (Gemini compound of Sodium lauroyl glutamate using Lysine).

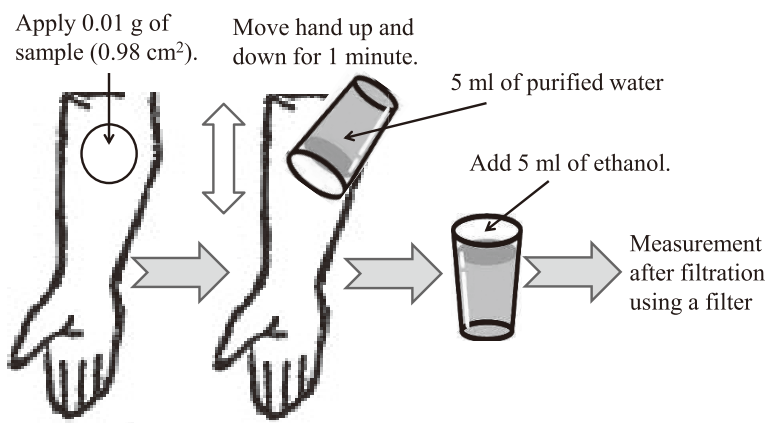

Fig.-2 Cup-shake method.

Water resistance test of the coated film and quantitative determination of UV absorber using the Cup-shake method.

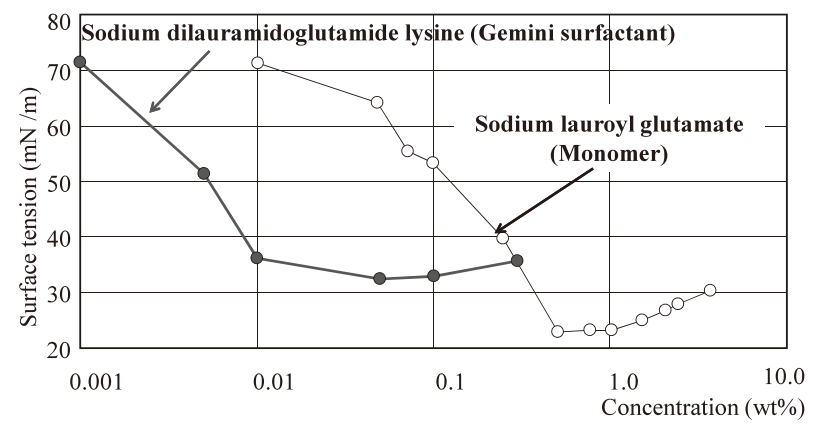

Fig. -3 Measurement of the surface tension using the Wihelmy method at $25^{\circ} \mathrm{C}$. 
擋挥しながら（5000 rpm）水相に油相を添加し（ジラウロ イルグルタミン酸リシン $\mathrm{Na}$ は水相に添加），5分間擋找を 続けた。終了したら手摚拌で室温まで泠却を行った。

\section{3. 粒子径測定}

レーザー回折散乱式粒度分布測定装置（LA-920；HORIBA 社）を用いて測定を行った。

\section{4. 耐水性試験}

試料 $0.01 \mathrm{~g} / \mathrm{cm}^{2}$ を前腕部内側に塗布し 5 分程度乾燥し た。その後, カップシェイク法により 1 分間上下に振った のちカップに移行した成分を液体クロマトグラフィー (HPLC) (Prominence；島津製作所社）を用いて分析を行っ た (Fig.-2)

\section{5. 撥水性試験}

撥水性は，乳化物などを実際の肌に塗布した表面を，携 带式接触角計 (PG-X;マツボー社)を用いて測定を行った。

\section{6. 毛髪に残存する油分量の測定方法}

毛髮に残存する油分の耐水性は，毛束 $(5 \mathrm{~g}, 10 \mathrm{~cm})$ に 乳化物を $3 \mathrm{~g}$ 塗布 $\Rightarrow$ 水洗 $(200 \mathrm{ml}) \Rightarrow$ 常温で一定時間放置 $\Rightarrow 10 \mathrm{ml}$ のクロロホルムで抽出 $\Rightarrow$ ガスクロマトグラフィー （GC）（GC-2014；島津製作所社）を用いて分析を行った。

\section{7. 生分解性試験}

生分解性試験は OECD ガイドライン 301 に準じて試験 を行った。

\section{3. 結 果 と考察}

\section{1. ジラウロイルグルタミン酸リシン $\mathrm{Na}$ の cmc (臨界ミセル濃度)}

ジェミニ型の界面活性剤の「ジェミニ (=双子)」とは, 1991 年に Menger らにより報告された論文の表題にある “Gemini-Surfactants”に由来する1),2)。「ジェミニ型界面活性 片」とは, その名のとおり，2つの一鎖一親水基型化合物 （モノマー）を連結（スペーサー）した構造であり，従来 のモノマーと比較して界面活性剤として高い機能を有す る。その特徵は,「親水性の保持」と「疎水性相互作用の 強化」というトレードオフの関係を解消している点であ り, 約 25 年前から現在に至るまで，その特徵に関心がも たれ，多くのジェミニ型化合物が合成され，ジェミニ型構 造にすることで得られる物性上の特徵などが多数報告され

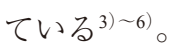

そこで，われわれも上記の特長に着目し，ラウロイルグ ルタミン酸 $\mathrm{Na}$ (モノマー）をスペーサーとしてリジンを 用いて連結させたペプチド骨格（グルタミン酸ーリジンーグ ルタミン酸のトリペプチド）を有するジラウロイルグルタ ミン酸リシン Na（Fig.-1）を合成し，実際にWilhelmy 法 で表面張力の測定を行った。その結果，ジェミニ型界面活 性剂ジラウロイルグルタミン酸リシン $\mathrm{Na}$ の cmc（臨界ミ セル濃度）は約 $0.01 \mathrm{wt} \%$ であり, ラウロイルグルタミン酸

Table-1 The results of emulsification of various types of oil using $0.03 \%$ Sodium dilauramidoglutamide lysine.

Evaluated result

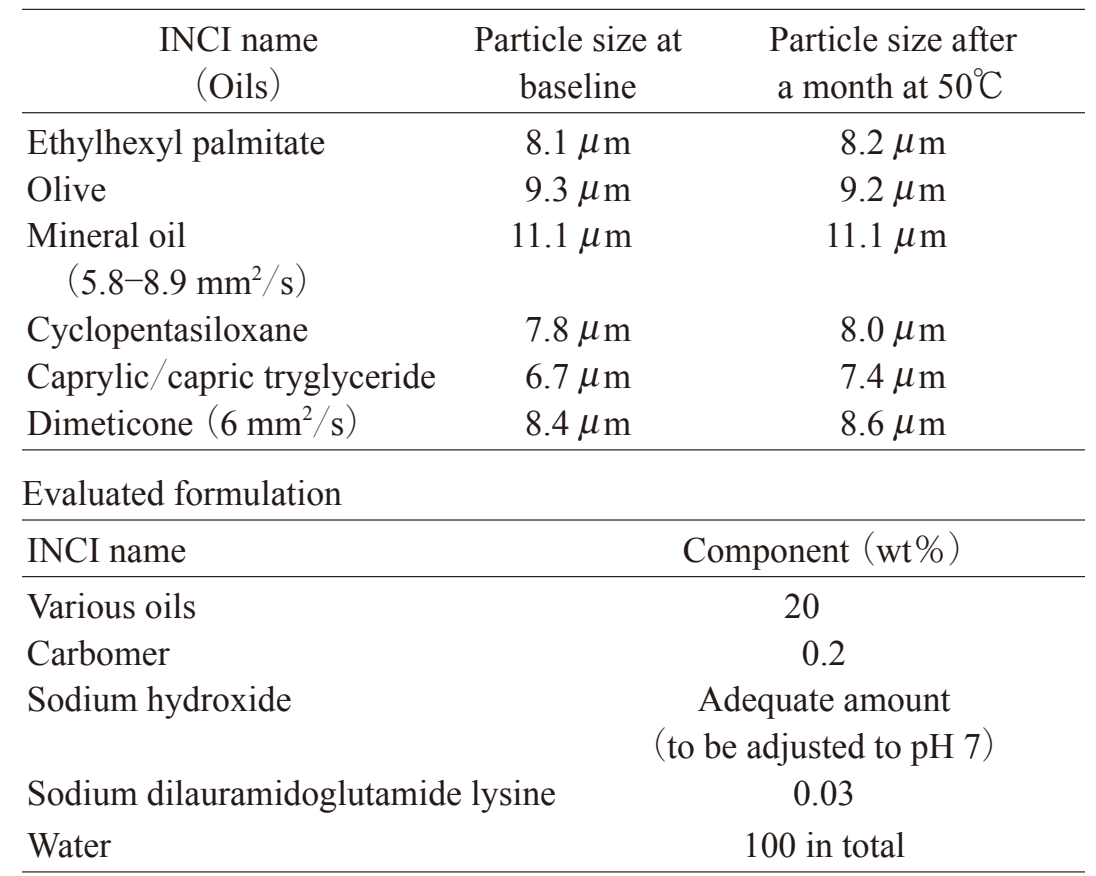


$\mathrm{Na}$ と比較すると約 50 倍も低いことがわかった（Fig.-3）。 この $\mathrm{cmc}$ が低くなる現象は, 一般的にいわれているジェ ミニ化することによる特長と一致した。

\section{2. ジラウロイルグルタミン酸リシン Na の乳化能}

各種油をジラウロイルグルタミン酸リシン $\mathrm{Na} 0.03 \%$ で 乳化した結果を Table-1に示す。粒子径は【初期】と 【50ㅇ，1 カ月後】ではほとんど変化していないことから, 油種によらず安定な乳化物が得られていることがわかる。 これは，ジラウロイルグルタミン酸リシン $\mathrm{Na}$ の構造が ジェミニ型であることから低濃度で高い界面活性能を有す るため乳化ができており, さらにアニオン系界面活性剤で あることから， $\mathrm{O} / \mathrm{W}$ エマルジョンの油滴の周りはアニオ ン性を帯びているために合一が起きにくく安定であること によると考えられる。さらにジラウロイルグルタミン酸リ シン Na $0.1 \%$ で油の種類と量を変化させて試験を実施した 結果, ジラウロイルグルタミン酸リシン $\mathrm{Na}$ の濃度に依存 せず安定な乳化物が得られることもわかった（Table-2）。

通常の HLB の概念で乳化の検討をすると, 油と水の界 面張力を下げて乳化させるので油の種類や量が変わること により，ノニオン系界面活性剂の量や配合比を変更したり する必要がある。しかし，ジラウロイルグルタミン酸リシ ン Naを乳化剂として用いると, そのような検討が不要 で，簡便に乳化が可能であることから処方検討の開発期間 が大幅に短縮できるメリットがある。
ただし、ジラウロイルグルタミン酸リシン $\mathrm{Na}$ を用いた 乳化は機械的に分散させた油の周りに界面活性剤が集まっ て乳化させるので, 乳化するときは下記の注意が必要であ る。

・水相にジラウロイルグルタミン酸リシン $\mathrm{Na}$ を添加 ・水相に油相を添加（反転乳化や転相乳化はできない）

・機械的な擋汼力が必要（ホモミキサーで $5000 \mathrm{rpm} 5$ 分 が目安)

このようにジラウロイルグルタミン酸リシン $\mathrm{Na}$ を乳化 剂として配合した場合，ノニオン系界面活性剂と比較して 少量（ $0.1 \%$ 以下）で乳化できるので，使用感（べたつき 感など）は格段に良くなることが明らかである。

\section{3. ジラウロイルグルタミン酸リシン Na 乳化物の 塗布膜に対する耐水性}

乳化物を皮膚に塗布した膜には乳化剂と油相成分および 一部の水相成分が混在する。ノニオン系界面活性剂乳化物 の場合は，数\%のノニオン系界面活性剤（特に高 HLB） が混在するために，水が付着すると表面張力の低下に伴い 再乳化して油相成分が流れ落ちてしまうが，ジラウロイル グルタミン酸リシン $\mathrm{Na}$ 乳化物は, そもそもジラウロイル グルタミン酸リシン $\mathrm{Na}$ が少量しか混在せず，かつ機械的 な分散が必要であるために，水が付着しても再乳化されに くいことが予想される。

そこで，塗布膜に対する耐水性試験を Fig.-2のような

Table-2 Tests by changing the type and amount of oil using $0.1 \%$ Sodium dilauramidoglutamide lysine.

Evaluated result

\begin{tabular}{|c|c|c|c|}
\hline \multirow{2}{*}{$\begin{array}{l}\text { INCI name } \\
\quad(\text { Oils })\end{array}$} & \multirow{2}{*}{$\begin{array}{l}\text { Required HLB } \\
\text { (Approx. value) }\end{array}$} & \multicolumn{2}{|c|}{ Particle size $(\mu \mathrm{m})$} \\
\hline & & Oil content $10 \%$ & Oil content $50 \%$ \\
\hline Triethylhexanoin & 4 & 7.0 & 4.6 \\
\hline Olive & 7 & 13.8 & 6.9 \\
\hline Cyclopentasiloxane & 7.5 & 8.5 & 6.9 \\
\hline Ethylhexyl palmitate & 8 & 8.3 & 5.4 \\
\hline Mineal oil & 10 & 11.3 & 7.3 \\
\hline Dimethyl phthalate & 15 & 1.0 & 1.1 \\
\hline \multicolumn{4}{|l|}{ Evaluated formulation } \\
\hline \multirow{2}{*}{\multicolumn{2}{|c|}{ INCI name }} & \multicolumn{2}{|c|}{ Component (wt\%) } \\
\hline & & Oil content $10 \%$ & Oil content $50 \%$ \\
\hline Various oils & & 10 & 50 \\
\hline \multicolumn{2}{|l|}{ Carbomer } & \multicolumn{2}{|c|}{0.2} \\
\hline \multicolumn{2}{|l|}{ Sodium hydroxide } & \multicolumn{2}{|c|}{ Adequate amount (to be adjusted to $\mathrm{pH} 7$ ) } \\
\hline \multicolumn{2}{|c|}{ Sodium dilauramidoglutamide lysine } & \multicolumn{2}{|c|}{0.1} \\
\hline \multicolumn{2}{|c|}{ BG } & \multicolumn{2}{|c|}{0.1} \\
\hline Water & & \multicolumn{2}{|c|}{100 in total } \\
\hline
\end{tabular}


Table-3 Water resistance test formulation (containing organic UV absorber).

\begin{tabular}{lcc}
\hline \multirow{2}{*}{ INCI name } & \multicolumn{2}{c}{ Content (wt\%) } \\
\cline { 2 - 3 } & Nonionic emulsion & $\begin{array}{c}\text { Sodium dilauramidoglutamide } \\
\text { lysine emulsion }\end{array}$ \\
\hline Glyceryl stearate & 1.0 & - \\
Ceteth-20 & 1.0 & - \\
Sorbeth-40 tetraoleate & 0.5 & - \\
Behenyl alcohol & 5 & 7 \\
Triethylhexanoin & 7 & 6 \\
Ethylhexyl methoxycinnamate & 6 & 2 \\
Benzophenone-3 & 2 & 0.3 \\
Carbomer & 0.3 & 0.1 \\
Sodium dilauramidoglutamide & - & Adequate amount \\
$\quad$ lysine & & (to be adjusted to $\mathrm{pH}$ 7) \\
Sodium hydroxide & Adequate amount & 100 in total \\
Water & (to be adjusted to $\mathrm{pH}$ ) & \\
\hline
\end{tabular}

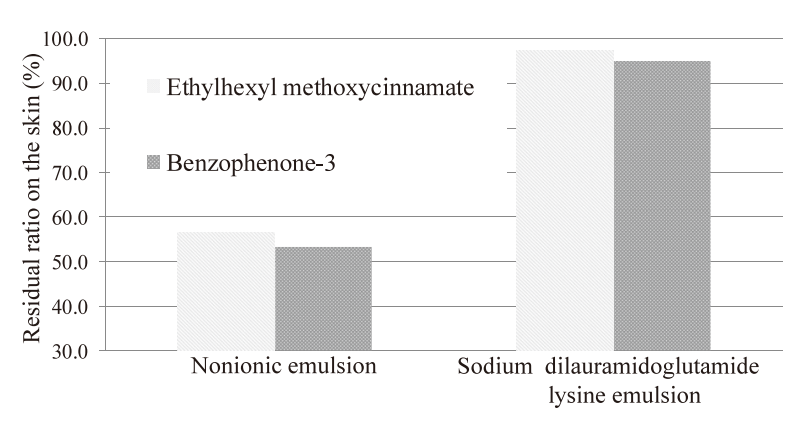

Fig.-4 Residual ultraviolet absorber on the skin surface. Residual ratio on the skin $(\%)=$ (Theoretical value-measurement) / theoretical value $\times 100$.

カップシェイク法で, 皮膚に塗布した乳化物中（Table-3） に含まれる有機系紫外線吸収剤がカップに移行した量を HPLCで定量を行った（Fig.-4）。この結果から，ジラウロ イルグルタミン酸リシン $\mathrm{Na}$ 乳化物はノニオン乳化物と比 較し，明らかに有機系紫外線吸収剂を皮膚に残存させる効 果に優れることがわかった。

さらに, サンスクリーン剤として市販されている製品と ジラウロイルグルタミン酸リシン Naを用いて調製した乳 化物の比較を行った（Table-4）。Fig.-5に示すとおり，ジ ラウロイルグルタミン酸リシン $\mathrm{Na}$ 乳化物の耐水性は, 市 販の $\mathrm{O} / \mathrm{W}$ 製品（製品 $\mathrm{B} ， \mathrm{C} ， \mathrm{D}$ ）に対し優れていたのは

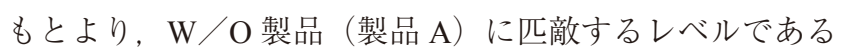
ことがわかった。市販品 $\mathrm{D}$ は $\mathrm{O} / \mathrm{W}$ 製品のなかで比較的 高い耐水性を示したが, これはジラウロイルグルタミン酸 リシン $\mathrm{Na}$ が配合されている影響であると推測される。

一方, 撥水性に関しても, ジラウロイルグルタミン酸リ

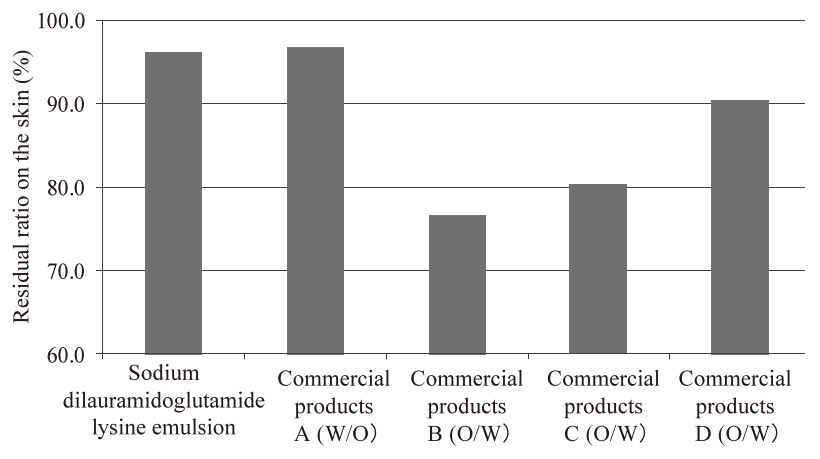

Fig. -5 Comparison of water resistant performance with commercial products.

Residual ratio on the skin $(\%)=$ (Theoretical value-measurement) / theoretical value $\times 100$.

シン $\mathrm{Na}$ 乳化物は市販の $\mathrm{W} / \mathrm{O}$ 製品（製品 $\mathrm{A} ）$ より劣るも のの, $\mathrm{O} / \mathrm{W}$ 製品（製品 $\mathrm{B}, \mathrm{C}, \mathrm{D} ）$ と同等以上のレベル にあることがわかった（Fig.-6）。

以上のように，ジラウロイルグルタミン酸リシン $\mathrm{Na}$ 乳 化物は少量で乳化できるため, 耐水性に優れた $\mathrm{O} / \mathrm{W} 工$ マルジョンであり，ノニオン系界面活性剤の使用量が少な いので使用感も良好であることがわかる。

\section{4. 毛髪に対する香料と油相成分の残留性}

香料は油相成分として配合されるのが一般的であること から, Table- 5 に示す乳化物の調製後, 毛髮に残存する油 分の測定の試験を実施した。

その結果は Fig.-7に示すとおりで，ジラウロイルグル タミン酸リシン $\mathrm{Na}$ で乳化した乳化物は非常に多くの香料 が毛髪に残存することが判明し, 明らかな差が認められ 
Table-4 Emulsion blend table and characteristics of commercial sunscreen.

\begin{tabular}{|c|c|c|c|}
\hline INCI name & Content $(w t \%)$ & & Features of \\
\hline Sorbitan stearete & 1.0 & & commercial product \\
\hline PEG-2 diisostearate & 0.2 & \multirow{3}{*}{$\begin{array}{r}\text { Commercial } \\
\text { product A }\end{array}$} & $\mathrm{W} / \mathrm{O}$ formulation \\
\hline Behenyl alcohol & 0.5 & & SPF50 + \\
\hline Titanium dioxide, Aluminum hydroxide, Stearic acid & 5.0 & & $\mathrm{PA}++++$ \\
\hline Ethylhexyl methoxycinnamate & 7.5 & \multirow{3}{*}{$\begin{array}{r}\text { Commercial } \\
\text { product B }\end{array}$} & $\mathrm{O} / \mathrm{W}$ formulation \\
\hline Octocrylene & 5.0 & & SPF50 + \\
\hline Cyclopentasiloxane & 3.0 & & $\mathrm{PA}++++$ \\
\hline Cethyl dimethinone & 1.0 & \multirow{7}{*}{$\begin{array}{r}\text { Commercial } \\
\text { product } \mathrm{C}\end{array}$} & $\mathrm{O} / \mathrm{W}$ formulation \\
\hline Polymethylsilsequioxane & 1.0 & & SPF50 + \\
\hline Sodium dilauramidoglutamide lysine & 0.1 & & $\mathrm{PA}++++$ \\
\hline Butylene glycol & 3.1 & & Containing Sodium \\
\hline Pentylene glycol & 2.0 & & acrylate/sodium \\
\hline Hydroxypropyl methylcellulose stearoxy ether & 0.2 & & acryloyldimethyl taurate \\
\hline Carbomer & 0.2 & & copolymer \\
\hline Xanthan gum & 0.2 & \multirow{7}{*}{$\begin{array}{r}\text { Commercial } \\
\text { product D }\end{array}$} & $\mathrm{O} / \mathrm{W}$ formulation \\
\hline Phenoxyethanol & 0.5 & & SPF50 + \\
\hline Ethylhexylglycerin & 0.5 & & $\mathrm{PA}++++$ \\
\hline Water & 100 in total & & Containing Sodium \\
\hline Potassium hydroxide & 0.02 & & acrylate/sodium \\
\hline Alcohol & 4.75 & & acryloyldimethyl taurate \\
\hline & & & $\begin{array}{l}\text { copolymer, Sodium } \\
\text { dilauramidoglutamide } \\
\text { lysine }\end{array}$ \\
\hline
\end{tabular}

Comparison of the emulsion prepared with Sodium dilauramidoglutamide lysine and commercial products sold as sunscreen agents.

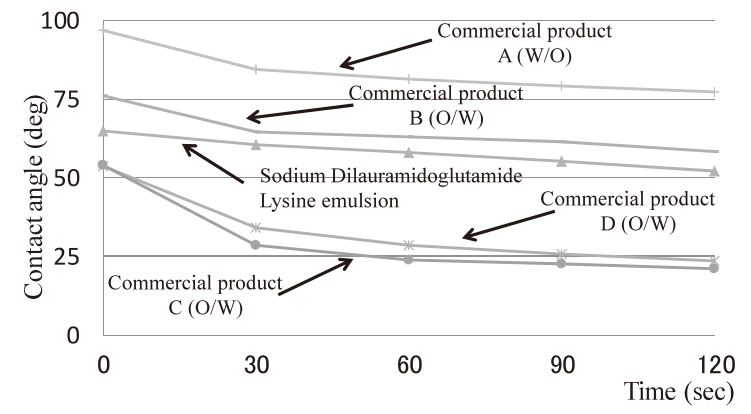

Fig.-6 Comparison of water repellent performance with commercial products.

た。さらに, 乳化物中の油相成分（ミネラルオイルとセ夕 ノール）が毛髪に残存する量も同様に測定すると, Fig.-8 に示すと㧍り，ジラウロイルグルタミン酸リシン $\mathrm{Na}$ で乳 化した組成物が一番多くの油相成分を残存することもわ かった。

このように，ノニオン系界面活性剤やカチオン系界面活 性剤と比較し, ジラウロイルグルタミン酸リシン $\mathrm{Na}$ で乳 化した組成物は，毛髪に塗布したのち水で濯いでも香料や 油相成分が毛髮に残留しやすいことから，処方中の香料の
配合量を減らせたりカチオン系界面活性剂を使用しないコ ンディショナーへの応用が期待できる。

一方，数十年前は無香料または微香性などの製品が多く 見られたが，近年は匂いを楽しむような製品が市場に多く 出回っているように思える。シャンプーやトリートメント も無香料や微香性といった製品は少なく，むしろ匂いに よって消費者は製品購入を決めているような風潮があると 思われる。

そこで，前に述べたように，ジラウロイルグルタミン酸 リシン Naで香料を乳化すると香料成分が毛髪に残留しや すいことから，カチオンコンディショナーの中にジラウロ イルグルタミン酸リシン $\mathrm{Na}$ で乳化した香料を添加した場 合の残香性につき，表面積の大きい高純度のシリカゲルに 気体を吸着・捕捉し，溶剤抽出して $\mathrm{GC}$ 分析を試みた。そ の結果，カチオンコンディショナーに単に香料を添加した 組成物と比較し, カチオンコンディショナーの中にジラウ ロイルグルタミン酸リシン $\mathrm{Na}$ で乳化した香料の乳化物を 添加したほうが，毛髪に香料がより多く残存することがわ かった。 
Table-5 Formulation of fragrance and oil content amount remaining on hair.

\begin{tabular}{lccc}
\hline \multirow{2}{*}{ INCI name } & \multicolumn{3}{c}{ Content $(\mathrm{wt} \%)$} \\
\cline { 2 - 4 } & $\begin{array}{c}\text { Sodium dilauramidoglutamide } \\
\text { lysine emulsion }\end{array}$ & Cationic emulsion & Nonionic emulsion \\
\hline Cetanol & 5.0 & 5.0 & 5.0 \\
Mineral oil & 5.0 & 5.0 & 5.0 \\
Limonene (Top note) & 10.0 & 10.0 & 10.0 \\
Benzyl acetate (Middle note) & 10.0 & 10.0 & 10.0 \\
Musk ketone (Last note) & 10.0 & 10.0 & 10.0 \\
Acrylates/alkyl acrylate (c10- & 0.2 & - & 0.2 \\
30) crosspolymer & & Adequate amount & Adequate amount \\
Sodium hydroxide & Adequate amount & (to be adjusted to pH 7) & (to be adjusted to pH 7) \\
& (to be adjusted to pH 7) & 0.5 & 0.5 \\
Betaine & 0.5 & 100 in total & 100 in total \\
Water & 100 in total & - & - \\
Sodium dilauramidoglutamide lysine & 0.1 & - & 0.5 \\
Glyceryl stearate & - & - & 1.0 \\
Ceteth-20 & - & 0.75 & - \\
PEG-20 hydrogenated castor oil & - & 0.75 & - \\
Cetrimonium chloride & - & & - \\
Behentrimonium chloride & - & &
\end{tabular}

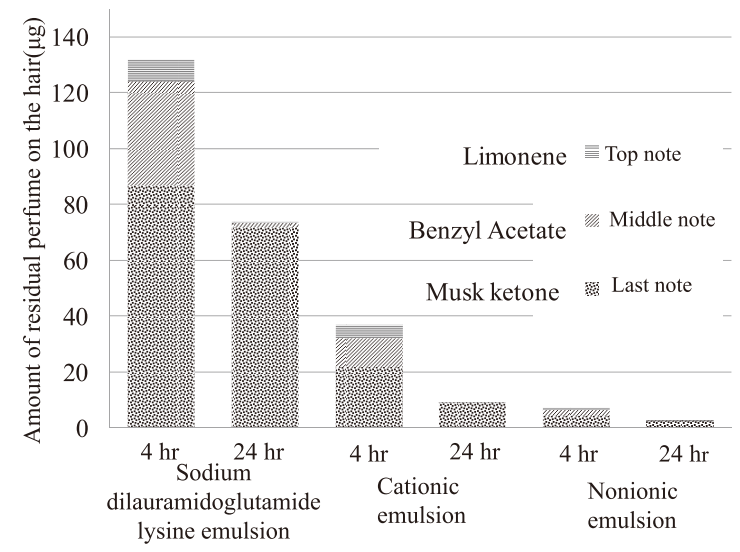

Fig.-7 Result of remaining perfume amount test on the hair (after drying for 4 and $24 \mathrm{~h}$ ).

\section{5. ジラウロイルグルタミン酸リシン Na の生分解性}

上記のようにジラウロイルグルタミン酸リシン $\mathrm{Na}$ は一 般的なノニオン系界面活性剤より少量で乳化ができること から，ジェミニ型にすることにより乳化剤市場全体の使用 量削減が期待できる。使用量の削減は環境に対して優しい ことから, OECD ガイドライン 301 に従ってジラウロイル グルタミン酸リシン $\mathrm{Na}$ の生分解性試験を行った。その結 果, Fig.-9 に示すと扔り生分解性は良好であることから,

ラウロイルグルタミン酸 $\mathrm{Na}$ をリシンで連結したジェミニ 型構造であるジラウロイルグルタミン酸リシン $\mathrm{Na}$ は「環 境に優しい界面活性剂」としての活用が期待できる。

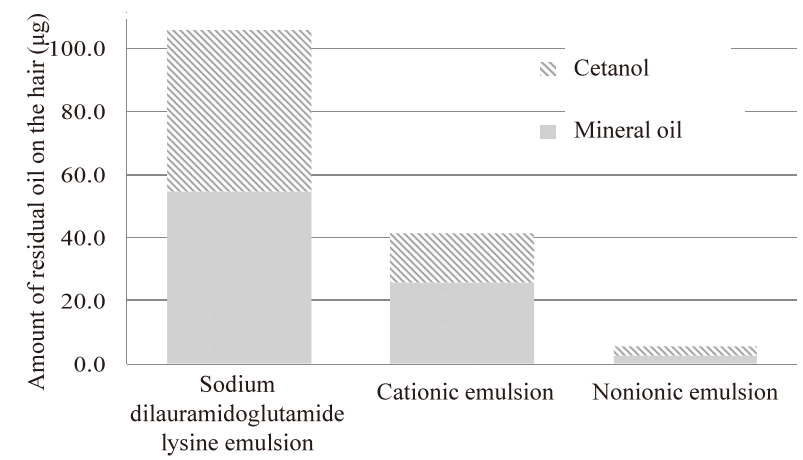

Fig. -8 Result of remaining oil amount test on the hair (after drying for $4 \mathrm{~h}$ ).

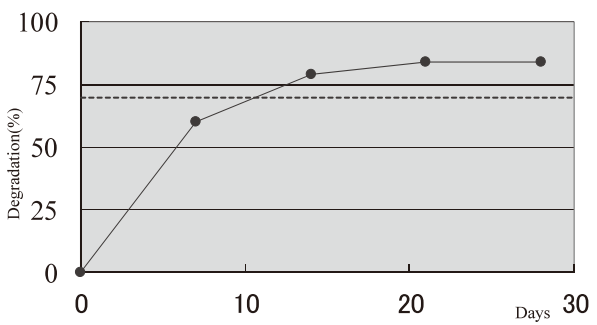

Fig. -9 Biodegradability of Sodium dilauramidoglutamide lysine. 


\section{4. 結論}

ジラウロイルグルタミン酸リシン $\mathrm{Na}$ は 2 鎖 3 親水基を 有するジェミニ型の構造を有しているので, ノニオン系界 面活性剤を乳化剤として配合する場合と比較して, 以下の ような特徴がある。

(1)油種や油の配合量に関係なく少量（0.1\%以下）で乳化 ができる（簡便に乳化ができるので開発期間の短縮が可 能)。

(2)少量で乳化ができるのでノニオン乳化物と比較して使用 感が良い。

(3)皮膚に塗布したあとの皮膜は耐水性が強いので紫外線吸 収剂や香料成分などの油相成分が皮膚や毛髪に残存しや すい。

また，ジラウロイルグルタミン酸リシン Na を用いた乳 化物の粒径は少し大きく， かつ少量で乳化しているので油 の感触がダイレクトに感じられ, 皮膚に塗布したときの伸 びが良く軽い使用感であることも特徵である。

一方，耐水性に関しては緒言でジェミニ型化合物が適し ているという論理を記したが，実際に試験を実施し観察す ると, 本考察の論理のほうが現象を的確に捉えていると思 われる。

このように，ジラウロイルグルタミン酸リシン $\mathrm{Na}$ を乳 化剂として用いると, 使用感に優れた耐水性 $\mathrm{O} / \mathrm{W}$ エマ ルジョンが簡便に調製できることがわかった。また, ノニ オン系界面活性剤を使用した既存処方に, ジラウロイルグ ルタミン酸リシン $\mathrm{Na}$ を添加すれば, ノニオン系界面活性 剤の配合量を大幅に減らすことも可能で, 得られた乳化粒 子もジラウロイルグルタミン酸リシン $\mathrm{Na}$ 単独での乳化に
比べ，細かくなることも確認できている。2 鎖 3 親水基の ジェミニ型界面活性剤であるジラウロイルグルタミン酸リ シン $\mathrm{Na}$ は, 従来では考えられない極少量の配合量で乳化 が可能であるなど，未知の可能性をもった素材であること がわかった。

最後に，ジラウロイルグルタミン酸リシン $\mathrm{Na}$ を約 $30 \%$ 含む水溶液は，医薬部外品（薬用化粧品の化粧水や薬用歯 みがき類等など）に新規添加剤として認められており，安 全性が確認されている。モノマー（ラウロイルグルタミン 酸 $\mathrm{Na}$ ）と同様に安全であることがわかる。また，生分解 性（OECD301C）もモノマーと同様に良好であることがわ かった。今後はジェミニ化することにより，乳化剤や可溶 化剂などの使用量が減らせることから「環境に優しい界面 活性剤」としての活用が期待できる。

\section{引用文献}

1) F. M. Menger, C. A. Littau, J. Am. Chem. Soc., 113, 1451 (1991)

2) F. M. Menger, C. A. Littau, J. Am. Chem. Soc., 115, 10083 (1993)

3）山本政嗣，富田 忍，新井裕之，フレグランスジャー ナル, 37 (5), 42 (2009)

4) R. ZaNa, J. Xia, GeminiSurfactants : Synthesis, Interfacial and Solution-Phase Behavior, and Applications, Marcel Dekker Inc., New York, 2003

5) M. J. Rosen, CHEMTECH, 23, 30 (1993)

6）阿部正彦, 鈴木敏幸, 福井 寛 編, 最新化粧品の機 能創製・素材開発・応用技術，エヌ・ティー・エス， 2007, p.193-232 